\title{
Difference Analysis of Interest Rate and Revenue Theory System on Banking
}

\author{
Haris Al Amin ${ }^{1}$, Syawal Harianto ${ }^{1}$, Dahlan Abdullah ${ }^{2}$, M Heikal $^{3}$, and Wahyuddin Albra ${ }^{3}$ \\ \{haris@pnl.ac.id\} \\ ${ }^{1}$ Department of Islamic Banking Finance, Politeknik Negeri Lhokseumawe, Aceh, Indonesia \\ ${ }^{3}$ Department of Informatics, Universitas Malikussaleh, Aceh, Indonesia \\ ${ }^{4}$ Department of Management, Universitas Malikussaleh, Aceh, Indonesia
}

\begin{abstract}
Banking as a financial institution has strategic role where its main activity is absorbing fund from society which surplus fund and channeling back to society with deficit of fund, enactment of dualbanking system giving birth two fund management system of banking interest rate system and profit sharing system. There are at least five approaches that serve as a distinguishing indicator between the interest rate system theory and profit sharing in the banking system as well as the five indicators, among others, the determination of the amount of profit, the amount of profit, the assumption of payment, the amount of payments, and the existence of the law and its validity.
\end{abstract}

Keywords: Conventional Bank, Dual Banking System, Interest Rate, Revenue System, Syariah Bank.

\section{INTRODUCTION}

Growth and development of the Indonesian economy cannot be separated from the growth and development of the banking world that encourages the economy through the activities of raising funds and the channeling of funds both through conventional banking and Islamic banks.

Banking as a financial institution has a strategic role where its main activity is receiving demand deposits, savings and deposits, then the bank is also known as a place to borrow money (credit) for people who need it. Absorbs funds from society that surplus funds and redistributes to society deficit funds [1]. With the enactment of the dualbanking law the system makes the financial management system in financial institutions and banking in Indonesia is divided into two ways which also gave birth to two different theories.

The first theory is the theory that has long been used in the economic system in Indonesia and the world that is the interest rate system. The second financial management system is a profit sharing system that has been seriously glimpsed since the onset of the global economic crisis in 1998. Both theories above each have different operational systems that have their own advantages and disadvantages in the theory or application. 


\section{METHODS}

The methodology used in this paper is a qualitative comparison method between interest rate theory and profit sharing in dual banking banking system in Indonesia which is seen in five aspects of indicator namely: the determination of the amount of profit, the amount of profit portion, the payment assumption, the amount of payment and its existence

\section{DISCUSSION}

\subsection{Interest Rate System}

Interest rates are one of the most important variables in the conventional economy which constantly influence both directly and indirectly the economy and social life of society, interest rates also influence the decision to invest or consume. Can we know the tendency of society when interest rates are high, people will automatically prefer to keep their money in the bank because he will get a high interest.

Conversely, if interest rates are low, people tend not to be interested anymore to keep their money in the bank and will withdraw their funds in the bank. From this it can be seen that interest rates have an important influence on public interest in the banking world.

Bank interest rates can be interpreted as a reward provided by banks that look at the principle of time value of money to customers who buy their products or when a bank or nonbank financial institution sells its products. Interest can also be interpreted as a price to be paid to customers (who have deposits) with which must be paid by customers to the bank (customers who get loans) [1].

In practice in banking, there are two prices that are always there namely the purchase price and the selling price. What if the bank collects funds from customers means the same as buying funds from customers, then later on the bank will pay a certain price to the customer in accordance with the initial provisions, therefore it can be said that the bank buy funds from customers with a certain purchase price is called deposit interest.

On the other hand banks will also sell funds to customers who need funds with a specific sale price in the agreement. The price is the selling price of the bank to the customer [2].

Interest is the dependency implied on the borrower of money, expressed as a percentage with the money lent or the loan term. Interest rates according to Sunariyah [3] is the price of the loan. Interest rates are expressed as a percentage of money perunit time. Interest rate is the cost of the loan or the price paid for the loan fund (usually expressed as percentage per year) [4].

According to Ismail [2] the application of interest contained in conventional banks can be separated into two types, namely:

a. Savings Interest Savings interest rate is a certain price level paid by the bank to the customer for the savings he made.

b. Interest on interest A loan interest or a loan interest is a certain price to be paid by the customer to the bank on the loan it receives.

For conventional banks, loan interest is the selling price charged to customers who need funds because conventional banking system thinks money is a commodity buakan tool of the transaction. In order to make a profit, the bank will sell the interest at a price that is relatively larger than the purchase price. This means, credit interest is greater than interest savings. 


\subsection{Share-sharing System}

Profit sharing in the economic dictionary means profit sharing. Definitively profit sharing means "the distribution of some part of the profits to employees of a company" [5]. In general, the principle of profit sharing in sharia banking can be done in four main contracts namely, al Musyarokah (shirkah), al Mudharabah, al muzara'ah, and al musaqoh [6]. The four contracts are a cooperation agreement between two or more people where there are parties who play sebahgai shahibul maal and there are parties who act as mudharib.

But common and often used in the application of Islamic sharia is al mudharabah and al musyarakah, while ak al al-ka'ahah and al-musaqoh rarely even not applied in Islamic banking because there is no special product designed for financing agricultural or livestock.

It is understood that the concept of profit sharing is essentially a collaboration between the owner of the fund and the fund manager where the results of the cooperation are divided in accordance with the agreement between the two parties by upholding the norms and values of the Shari'a.

Philosophically, the profit-sharing system prevents economic oppression and distributes the economy's economic well-being, in line with the goal of establishing a banking institution.

The interest and profit-sharing differences can be at least observable from the following five aspects or indicators, the first indicator is the determination of the amount of profit.

Table 1. Profitability Determination Indicators.

\begin{tabular}{ll}
\hline Interest & Profit sharing \\
\hline $\begin{array}{l}\text { The determination of interest is made at } \\
\text { the beginning of the contract with the }\end{array}$ & $\begin{array}{l}\text { The determination of the ratio of profit / profit } \\
\text { sharing ratio is made at the time of the contract } \\
\text { assumption should always be a profit. }\end{array}$ \\
\hline
\end{tabular}

The indicator of the determination of the profit gain on a profit-making interest system is made at the beginning of the contract with the assumption that it must always be profitable.

For example, the bank promises a savings rate of $2 \%$ per year to depositors (buy) from the amount of savings, then the banks sell back the purchased money at $2 \%$ to customers who need money or funds at $4 \%$ per year. Indirectly the bank has made an agreement to the savers customers at the beginning of the contract will reward $2 \%$ of the funds that are held with the assumption of always a profit, on the other hand the bank also requires the customer to borrow capital to return $4 \%$ of the amount of money borrowed with the assumption always fortunately also without seeing the business condition of the customer.

In sharia banking Indicator of the determination of the amount of profit is determined based on the ratio / profit sharing ratio made at the time of the contract with reference to the possibility of profit and loss.

For example from the 10 million money in the tube agreed on profit-sharing ratio or ratio of 50:50 of the profit earned by the bank from the proceeds of managing the 10 million funds to the party financed by the sharia bank with the profit-sharing ratio or the ratio at 50:50 as well.

So what if the customers who financed by Islamic banks get 500 thousand profit per month then the Islamic bank will get $50 \%$ profit that is equal to 250 thousand and financing customer gets $50 \%$ also that is equal to 250 thousand also. The savers get $50 \%$ of the 250 thousand earned by the sharia bank that is equal to 125 thousand and Islamic banks also get $50 \%$ profit of 125 thousand. The second indicator is seen from the size of the profit portion 
Table 2. Indicator of Profit Share

Interest
$\begin{aligned} & \text { The percentage is based on the time period and the } \\ & \text { amount of money (capital) that is lent. }\end{aligned}$
Source: Antonio [6]
based on the amount of profit earned.

Table 3. Payment Assumptions

\begin{tabular}{ll}
\hline \multicolumn{1}{c}{ Interest } & \multicolumn{1}{c}{ Profit sharing } \\
\hline $\begin{array}{l}\text { Fixed interest payments as promised } \\
\text { without consideration of whether the project } \\
\text { run by the customer profit or loss. }\end{array}$ & $\begin{array}{l}\text { Profit sharing depends on the profit of the } \\
\text { project being undertaken When the business } \\
\text { loses, the loss will be shared by both parties. }\end{array}$ \\
\hline
\end{tabular}
Source: Antonio [6]

Table 4. Payment Amount.

\begin{tabular}{ll}
\hline \multicolumn{1}{c}{ Interest } & \multicolumn{1}{c}{ Profit sharing } \\
\hline $\begin{array}{l}\text { The amount of interest payments does not increase } \\
\text { even if the amount of profit doubled or the state of } \\
\text { the economy is "booming" }\end{array}$ & $\begin{array}{l}\text { The number of profit sharing increases } \\
\text { accordingly with an increase in the } \\
\text { amount of revenue }\end{array}$ \\
\hline
\end{tabular}

As an illustration on the indicator of the determination of the amount of profit seen in the assumption of payment it can be seen if conventional banks get big profits then the customer will get a predetermined profit that is $2 \%$ no more and the same portion and if conventional banks experience small profits or losses then the customer also get $2 \%$ profit too.credit customers also experience the same thing when their business is profitable.

Conventional banks only get $4 \%$ of their invested capital even though customers experience a boom in profits, and still pay $4 \%$ of the borrowed capital even though their business is being dropped or decreased dependence.

This is different from the pattern applied by sharia banks if the bank gets a big profit then the penabungpun customers will get a large profit for example the ratio agreed 50:50 if the Islamic bank to profit 1 million customers will get 500 thousand banks 500 thousand if the Islamic bank to obtain 1.5 million then the customer earns 750 thousand banks also get 750 thousand, whereas if the bank has decreased keuantungan such as 500 thousand customers only got 250 thousand banks got 250 thousand.

The same is true with financing customers if customers get 1 million with a ratio of 50:50 agreed 500 thousand customers get 500 thousand what if 2 million banks will get 1 million and customers also 1 million and if it decreased the bank's equity as well decreased profits. The fifth indicator is existence 
Table 5. Existence

\begin{tabular}{ll}
\hline \multicolumn{1}{c}{ Interest } & \multicolumn{1}{c}{ Profit sharing } \\
\hline $\begin{array}{l}\text { The existence of interest is doubtful (if not } \\
\text { criticized) by all religions, including Islam. }\end{array}$ & $\begin{array}{l}\text { No one doubts the validity profit } \\
\text { sharing. }\end{array}$ \\
\hline
\end{tabular}

Source: Antonio [6]

The existence of a flower system is not justified in all of the celestial religions. Both Jews, Greeks, Romans and Christians in [6] are listed in the scriptures of each of these religions, in contrast to the profit-sharing system found no such restrictions as the flower system.

This proves that the system comes from God is the best system then the economic system is also what if you want to be good should use the system that has been in God in God's holy book bukn economics results of human thought alone.

For example, if the solar system that exists in space follows the system or the rules of human beings, of course pelanet-pelanet, the stars, the sun and other celestial objects collide with each other, but because the solar system in the sky follow the system or God rules then there is harmony and balance so there is no chaos.

As to which Allah says in Surah al mulk Verse 3 which means "Who has created the seven heavens in layers. You have not seen the creation of a merciful God of unbalanced things. Then look again and again, do you see something unbalanced?" [7].

Likewise in other living systems not only the economic system alone when applying the system advocated by God through his treatise or scripture then it is certain will be the best system for all living things.

Therefore, in Islamic banking using the system advocated by God does not experience or there is a term negative spread or failure to pay either from the customer or the bank's own financing. Because essentially the existence of a banking institution is an intermediary institution between an excess of funds with a party lacking funds that aims to improve the common welfare, rather than creating the social gap as it is now.

The purpose of establishing sharia banking to answer bahwasannya Islam is a perfect religious teachings that have a system and mechanism way bermuamalah separate, because Islam is a source of values and ethics in aspects of life as a whole [8].

The principle of ketauhidan is the most basic foundation of Islamic economics [9]. This is what underlies the values in the movement of syraiah banks as well as the difference between the conventional system with the sharia bank system

\section{CONCLUSIONS}

Interest rate system is a system born from human thinking so there are many imbalances of this system. While the profit-sharing system is a system born of God it appears that all religions that come from the sky opposed the flower system.

Of the five comparator indicators, the profit sharing system seems to be more prosperous for the community and the banking sector because the concept of Islamic banking is a holder of the mandate of the deposited funds rather than the owner of the deposited funds. 


\section{REFERENCE}

[1] Kasmir, Bank dan Lembaga Keuangan Lainnya. Jakarta: Raja Grafindo Persada, 2014.

[2] Ismail, Manajemen Perbankan. Jakarta: Kencana Prenada Media Grup, 2011.

[3] Sunariyah, Pengantar Pengetahuan Pasar Modal. Bandung: Alfabeta, 2004.

[4] F. S. Mishkin, Ekonomi Uang, Perbankan,dan Pasar Keuangan. Jakarta: Salemba Empat, 2008.

[5] Muhamad, Teknik Perhitungan Bagi Hasil dan Pricing di Bank Syariah. Yogyakarta: UII Press, 2012.

[6] M. S. Antonio, Bank Syariah: dari teori ke praktik. Gema Insani, 2001.

[7] Tim Syaamil Al-Qur'an, Syaamil Al-Qur'anulkarim Miracle The Refference. Bandung: Creative Media Corp, 2011.

[8] M. J. Hidayat, An Introduction to The Sharia Economic. Jakarta: Zikrul Hakim, 2010.

[9] A. H. Usma, Manajemen Startegis Syariah. Jakarta: Zikrul Hakim, 2015. 